\title{
Emerging Cultural Conflicts in Italy: A Challenge for Criminal Law
}

\author{
Raffaele Muzzica ${ }^{1}$, Tracy L. Tamborra, ${ }^{2, *}$ and Giuseppe Amarelli ${ }^{1}$ \\ ${ }^{1}$ Università degli Studi di Napoli Federico II, Naples, Italy \\ ${ }^{2}$ University of New Haven, West Haven, USA
}

\begin{abstract}
Because of recent and rapid increases in immigration rates, Italy has been confronted with new forms of cultural conflicts. Cultural conflicts have resulted in cultural offenses; these are acts committed and promoted by people belonging to a minority culture that are considered to be offenses by the majority controlled legal system. In addition to defining cultural offenses and presenting defenses that are presented when cultural offenses are tried, this paper highlights pros, cons and potential pitfalls of considering culture under Italian law. Finally, suggestions to improve legal considerations of cultural diversity in Italy are presented; specifically the creation of laws to exculpate offenders of minor cultural offenses, the prioritization of justifications over excuses as a legal defense, and mitigated punishments in cases of major cultural offenses.
\end{abstract}

Keywords: Culture conflicts, cultural offenses, cultural defenses, Italian law, criminal law and culture.

Cultural conflicts affect all levels of social relationships between the existing majority culture that maintains control over all institutions and the minority cultures that are expected to acculturate. These conflicts play out in both private and public spheres; one of the most notable conflicts occurs when courts are confronted with cultural offenses. Although, defining a culturally based offense can be complicated, numerous authors have expressed the need to define a cultural offense (Basile, 2010; Bernardi, 2010; De Maglie, 2010; Foblets, 1998); and have therefore cited the definition put forth by Van Broeck (2001), "A cultural offense is an act by a member of a minority culture, which is considered an offense by the legal system of the dominant culture. That same act is nevertheless, within the cultural group of the offender, condoned, accepted as a normal behavior and approved or even endorsed and promoted in the given situation" (p. 5). Furthermore, the Harvard Law Review (1986) situates these offenses in societies, where cultural fragmentation has a deep impact also on criminal law. One such country that is currently experiencing this transition is Italy. The total number of immigrants in Italy increased from approximately 356,159 in 1991 to $4,387,721$ as of January, 2013; the most dramatic increases were noted between 1991 2001 in which the number of immigrants in Italy tripled (ISTAT, 2009; ISTAT, 2012b; ISTAT, 2013a). Furthermore, newly imported religions and their associated customs and practices further complicate this discussion.

Although increases in immigration rates alone do not automatically create culture conflicts, in terms of

*Address correspondence to this author at the University of New Haven, West Haven USA; Tel: 1 (203) 479-4591; E-mail: ttamborra@newhaven.edu application of the law, a more homogenous society will be more perplexed by cultural offenses. Caputo (2005) notes that Italian policies tend to be inspired by severe cultural homogenization and a discriminatory attitude toward cultural diversity. Furthermore, this reliance on cultural homogeneity is reflected in the Italian Penal Code report. Bernardi (2010) and De Maglie (2010) both note that the report includes the following quote, "Lo Stato ci appare come la nazione medesima in esso organizzata, cioè come un'unità non solo sociale, ma altresì etnica, legata da vincoli di razza, di lingua, di costume, di tradizioni storiche, di moralità, di religione" (The State seems to us as the nation itself is organized, actually as a unit not only social, but moreover ethnically, tied by bonds of race, of language, of customs, of historic traditions, of morality, of religion) (p. 62; p. 34). Finally, Grosso (2006) notes that the Italian Constitution is also based on a shared cultural pattern of values.

The intersection of the sudden increase in immigration rates, and socio-politically homogeneous preferences suggest that Italy may be unprepared to consider and legally address cultural offenses. This lack of preparation may be a product of the relatively few discussions on this topic. Therefore, the overall purpose of this paper is to expose the reader to the complexity, both philosophically and pragmatically, associated with cultural offenses and subsequently employed cultural defenses, such as justifications and excuses, presented in Italian courts. In order to accomplish this task, this paper first presents data regarding rising immigration rates in Italy. Next, this paper defines culture and explores the relationship between law and the evolution of culture. Subsequent sections examine cultural defenses, as well as consider 
whether punishment determinations should consider culture as a mitigating factor. The pros, cons and potential pitfalls of acknowledging cultural offenses under Italian law are then considered. Finally, a discussion of how and why Italy should legally recognize cultural offenses and therefore defenses, is put forth.

\section{IMMIGRATION RATES}

ISTAT (2009) reported that there were 3,423,651 immigrants in Italy, in 2008. Of this group, there was an approximate 50/50 split between men and women, and the majority settled in Northern Italy. Additionally, ISTAT (2013a) reported there were over 4,000,000 foreign national residents in Italy, as of January 2013. In addition to this, the immigration growth rate is nearly twice that of the national average rate (ISTAT, 2012a). However, it should be noted that these are mostly likely underestimates because they do not capture undocumented immigrants or to short-term visitors, and both of these categories may affect rates of cultural offenses. As such, it has been estimated that 5 million immigrants were reported in Italy in 2011 and that $10 \%$ were undocumented immigrants (European Migration Network, 2012; Eurostat, 2011).

In addition to the numbers of immigrants present in Italy, immigrants' countries of origin, religions, and economic statuses are worth noting. According to ISTAT (2013b), 2012 data indicate that most immigrants came from either Eastern Europe (Romania and Albania) or Northern Africa (Morocco, Tunisia, Egypt). Although ascertaining exact religious affiliation data from Italy can be complicated, data indicate that estimates of Catholics in Italy have decreased in recent years. EURISPES (2010) indicate that $76.5 \%$ of Italians report that they are Catholic compared to EURISPES (2006) data that indicated $87.8 \%$ was Catholic. Reports also indicate that approximately $33 \%$ of immigrants practice Catholicism and $11 \%$ are atheist or agnostic, the remaining immigrants practice other religions such as Islam, Hinduism, and Buddhism (Institute of CaritasMigrantes, 2011). Finally, the rate of unemployment is reported to be higher among immigrants than nationals, $14.1 \%$ versus $10.7 \%$ respectively. Collectively the data reveal that immigration rates in Italy are rapidly increasing, newly imported religions are also increasing, and that new immigrants are more likely to be unemployed. Therefore, it is safe to assert that immigrants in Italy, in general, represent an ethnic and religious minority, and also are economically disadvantaged. These factors must be considered when discussing cultural conflicts in emerging intercultural societies.

\section{CULTURAL: A COMPLEX WHOLE}

Basile (2010) notes that Tylor (1871) considers culture to be a complex whole, which includes every human activity; moreover, culture is something acquired, not inborn in the individuals. Furthermore, Basile also references Kluckhohn and Kroeber (1952) who suggest that cultural systems consist of explicit and implicit patterns of behavior, in which people learn and teach through symbols, as a means of summarizing and transmitting ideals. Geertz (1973) also considers the importance of the transference of symbols, "Culture is a historically transmitted pattern of meanings embodied in symbols, a system of inherited conceptions expressed in symbolic forms by means of which men communicate, perpetuate, and develop their knowledge about and attitudes toward life" (p. 89). Therefore, culture is not a static system; a pure culture does not exist. As a result, culture does not exist in and of itself, but only in connection with a group. If individuals could not change and rearrange their patterns of behavior with reference to their life experiences, culture would cease to exist.

The transmission of cultural traditions and values occur at least twice for persons who are minorities in a society, first, through the process of enculturation. Enculturation is a cultural process by which individuals are influenced by their own historical culture (most often during childhood), consciously or even unconsciously. It may be defined as the process by which individuals acquire the knowledge, skills, attitudes, and values (all of them can be called as "ingroup values") that enable them to become functioning members of their societies (Foblets, 1998). "Individuals, because of enculturation, feel compelled to respond to stimuli in differing ways. Culture affects their perceptions and behavior in powerful ways, without being conscious of it" (Renteln, 2009, p. 796).

Next, minority groups (either indigenous or foreign) may have their cultural traditions contested, challenged, or changed in some other way that forces them to adapt to the majority culture; this is known as the acculturation process. Acculturation can be described as the process by which individuals rearrange and change their own cultural values because of blending with other cultural patterns (Van Broeck, 2001). Minorities may spontaneously acculturate, but it is more likely that the dominant group 
compels the minority group to acculturate by imposing their cultural values upon them, and encouraging and/or forcing the minority group to abandon their culture; in this way acculturation becomes an homogenization process. However, the social reality is that some minority groups, when faced with the pressure to assimilate to the dominant culture, do not always abandon their own values. On the contrary, core values can be enshrined and reinforced, in order to preserve one's traditional identity. Subsequently, minorities may be more dependent on their social groups, further reinforcing the need to preserve their cultural identity. In this sense, although the majority culture wants the minority to abandon his/her values and "acculturate", this process could produce minority culture members who are more vested in preserving their cultural origin.

In conclusion, culture is a dynamic, complex manifestation of history and values, often embodied in symbols. Members of a group fluidly transmit and inherit these symbols, consciously or otherwise through the enculturation process and are then confronted with the transmissions of culture through acculturation process when they become or realize that they are a minority in the larger society. Furthermore, intercultural societies may have a greater set of problems as these societies are categorized by daily interactions between the majority and minority groups (Valier, 2003).

Although culture is a multifaceted concept, pertaining to race, class, sex, sexuality, religion, nationality, etc., this paper will focus on the aspects of culture in which the individual is influenced by a system of normative rules, embodied in traditions and mores, that define how the individual member of the minorities groups is likely to act in particular circumstances based upon his/her self-perceived identity. Furthermore, it is arguable that people consolidate their identity in acting in compliance with their traditions, because on the one hand, traditions act as a compelling factor for members who share them; but on the other hand, they represent one's deep identity against disintegration when persons from differing cultures interact. These interactions can result in cultural conflicts. Although cultural conflicts can result from the same list of demographic factors listed above, this paper will focus on cultural conflicts resulting from clashes between non-Catholic, poor, immigrant minorities and Italian law, which is the most affective homogenizing instrument of the majority culture.
CULTURAL OFFENSES: A CLASH BETWEEN NEW CULTURES AND ESTABLISHED LAWS

Campbell (2012) points out that, as noted by Gustav Radbruch, "law is a cultural phenomenon"; however, law does not generally explain its relationship to culture or acknowledge the culturally motivated origins of such law. Even more so, criminal law is arguably further linked to culture, because of its innate role to defend values and the national identity. If culture is seen as a social scheme conveying implicit or explicit patterns of behaviors, law should be considered one of the most binding and broad agencies able to influence actions. Furthermore, it has been argued that penal codes are the most powerful weapon that the majority culture possesses in terms of maintaining control over minority groups (Baratta, 1976). Consequently, the law enforces the norms of the dominant culture in order to maintain its dominance (Campbell, 2012; Post, 2003). Nevertheless, some requirements are needed in order to assess if a cultural conflict amounts to a true cultural offense.

De Maglie (2010) lists what is required to define a cultural offense; firstly, there has to be a relevant link between the offense and the cultural background of the defendant. Therefore, the defendant's cultural mores must be able to "explain" the core of the fact. Secondly, it must be established that the cultural motivation can be generalized; that is to say that the cultural offense must not be motivated by the offender's personal beliefs, but rather by the culture and heritage of the minority group to which the defendant belongs. Nevertheless, this ascertainment must always consider that cultural behavioral patterns are not standardized, but they vary due to social positions; Van Broeck (2001) notes, "when dealing with cultural offenses, that one does not have to ask the question whether or not every member of that culture should act the same way in the circumstances at hand. Rather, the question should be whether or not the offender should have reacted as he or she did" (p. 11).

In addition, Renteln (2004) notes that cultural evidence should be considered, as culture shapes cognition and conduct of individuals. Furthermore, respecting one's cultural identity is considered to be a "polyethnic right" that immigrants should be entitled to, although they have no prior relationship with the host country (Meer \& Modood, 2012). This is of particular importance as Italy rapidly becomes an intercultural country. Although Italy has been considered for centuries a multicultural country (i.e., regional 
differences resulting in varying dialects, customs and rituals), increasing rates of non-Catholic, poor, immigrants have created tension. In this way, Italy is not different from other Western societies affected by globalization trends. Therefore, Italian law should focus consider an offender's culture; this consideration should be conveyed through cultural defenses.

Justifications and excuses as "cultural defenses": Should culture negate responsibility?

The definition of a cultural defense is not contained in any statutes or official report, however the term has been discussed by several authors (Chiu; 1994; Foblets, 1998; Harvard Law Review, 1986; Mezzetti, 2013; Renteln, 2009; Van Broeck, 2001). A cultural defense pertains to any doctrine that recognizes a defendant's "cultural background to negate or mitigate criminal liability" (Kim, 1997, pp. 102 - 103). Cultural defenses, even in the most multicultural of societies, such as the U.S., are frowned upon because they have been viewed as incompatible with the Rule of Law (Heller, 2012). Furthermore, Italian law does not recognize such defenses, given the fact that it has only recently been confronted with such considerations (Monticelli, 2003). Therefore, we cannot reference specific Italian cases in which a cultural defense was officially used. As such, we put forth two examples of widely known U.S. cases; these cases are often cited in Italian legal scholarship. In the case People $v$. Kimura, No. A-09113 (L.A. Sup. Ct. 1985), a JapaneseAmerican woman attempted to commit oyako-shinju (parent-child suicide) after learning that her husband was unfaithful. It was argued that killing yourself and your children is a customary response in her situation. She was sentenced to probation as a result of a temporary insanity defense, on account of the cultural conflict in which she had found herself.

Additionally, in People v. Moua, n. 315972-0 (Fresno County), Kong Moua, of Hmong culture, was accused of raping and kidnapping a woman of his group, after performing the required courtship. He claimed that he wanted to realize zij poj niam or marriage by capture, according to his cultural tradition. The defendant argued that he had made a mistake of fact, compelled by his cultural beliefs about zij poj niam. The Court allowed him to enter a plea for a reduced false imprisonment charge and completely dropped the rape charge, although the Hmong community and victim family did not recognize the fact as zij poj niam.
Although Italian law does not recognize the general concept of a Common Law "defense", and Italian law does not provide a specific doctrine to convey offender's cultural background in the trial, judges tend to use justifications and excuses when presented with a cultural offense (Monticelli, 2003). Under Italian law there are differences between what could be considered to be justifications and excuses. Among several doctrines that can be used in a trial to put forward cultural factors, the exercise of a right Justification (Article 51 of the C.P.) and the mistake of law Excuse (Article 5 of the C. P.) represent the most noteworthy references to this issue.

\section{Justifications}

Justifications, such as self-defense or the exercise of a right, serve as just causes for committing an act that would otherwise be unlawful (Horowitz, 1986). They are considered to be the point at which social conflicts can be addressed by criminal law in that justifications reflect the social order of interests since justified acts are not considered to be socially undesirable facts by law (Roxin, 1973). Therefore, the person responsible for a justified act does not have to be rehabilitated through punishment. Even when a justified act is not considered to be a good action (e.g., the death of the offender), justifications always reflect what the law considers to be the right action to take in a particular case. Furthermore, justifications discourage crimes by legitimating a forcible response to them. As a result, they may be applied also to a third-party who assists the actor (Horowitz, 1986). Moreover, the perpetrator who becomes the victim of a justified action (e.g., self-defense) has no right to defend him/herself, whereas the perpetrator who becomes the victim of an excused act has the right to defend against it.

Article 51 of the Codice Penale (C.P.) justifies offenses committed by an offender who is practicing a right, because the law cannot forbid an act that is also considered to be an exercise of a right. But this doctrine does not define what a right is and what the boundaries are; therefore this doctrine is widely criticized by some authors. For instance, Viganò (2006) notes that this doctrine seems to place these rights over the offense, rather than describing the limits of the right in relation to the offense.

Therefore, the question is whether the right to one's culture justifies offenses prohibited by law. To answer this question, one must first consider that culture as a human right, is recognized under various Italian laws 
and International Covenants. Article 27 of the International Covenant on Civil and Political Rights (ICCPR) enacted in 1978 stated that ethnic and religious minority groups cannot be deprived of the right to have their own cultural life and to practice their own religion and language with their other members of their group. In addition, Article 9 of the European Convention on Human Rights (ECHR), Article 18 of the ICCPR and Articles 2, 19, and 21 of the Italian Constitution also establishes that persons have the right to freedoms of thought, conscience and religion, including religious practices.

Although it seems culture is recognized as a fundamental human right, inner and outer boundaries of the concept need to be defined in order to balance it with other important interests that can require criminal law enforcement. For instance, the act must be justifiable and proven to be an exercise of the person's rights; the defendant's intent is not enough to make the act lawful (Del Corso, 2011; Viganò, 2006). Furthermore, the type of offense committed must be a consideration. For instance, offenses that offend supreme interests must be excluded from justification. We should note that supreme interests under Italian law cannot be listed or readily defined, as they emerge in judicial evaluations. However, rights explicitly defined as "inviolable" by the Italian Constitution or international covenants can be considered supreme interests; they represent core values of Italian society. Supreme interests can be set aside only when specific legal conditions occur, but hardly ever for cultural factors. Furthermore, Viganò (2006) and Provera (2010) deem that religious freedom cannot be limited to worship, promotion and religious beliefs, but it has to include the freedom to live according to one's own beliefs; that is a concept very similar to culture. Therefore, neither religious freedom nor the right to culture can justify the actions and therefore exempt from punishment, a defendant who has offended a supreme interest such as the deprivation of life, freedom, and sexual liberty, for instance, in order to exercise religious beliefs or right to uphold cultural norms.

It is arguably easier to exclude from justification, offenses that are meant to inflict serious harm (e.g., murder or rape) while upholding cultural norms. However, the more complex discussion pertains to offenses that do not offend supreme interests and/or those that are trivial or not very harmful, such as bigamy, incest (between adults), the possession of ritual (illegal) drugs, environmental crimes (e.g., the throwing of human remains in nature), and the criminalization of wearing traditional clothing (burqas and turbans). In fact, if law punished such cultural offenses, rehabilitation and social cohesion alike would be made impossible. Italian judges seem to accept this premise. For instance, the Court of Cremona (sent. 19/02/09, n. 15) acquitted a Sikh worshipper of illegal weapon possession (Sikhs carry a small knife called kirpan), because Italian law 110/1975 does not forbid weapon possession when a "justifiable reason" is presented. The judge issued an acquittal and noted that the act was justified as the defendant has a right to exercise his religious freedom (art. 19 Cost). In another case described by Gatta (2009), a woman wearing a burqa was before the court for violating the antiterrorism law 152/1975. The law prevents people from being unrecognizable, by helmets, scarfs and anything else; however, the law does not forbid covering onesself when there is a "justifiable reason". The woman was eventually acquitted, but the Court did not evaluate if a cultural factor could have amounted to a "justifiable reason." Instead, the acquittal was reached, according to the judge, because the woman had not performed a crime, since she had uncovered her face, when asked by a policewoman (in a private room), in order to be identified.

In conclusion, although an intercultural society has to put some limits on individualized expressions of behavior, the right to culture should be prioritized when there is no risk of endangering human rights or offending against supreme interests. Therefore, cultural differences must be protected through criminal law when they represent a way to preserve minority groups from majority interference. External protections, according to Kymlicka (1995) such as statutory exemptions from dress codes and permission to use reasonable amount of ritual drugs should be afforded to minority cultures.

\section{Excuses}

Excuses, on the contrary, are an exculpatory category by which the actor is exempted by punishment on account of abnormal conditions (e.g., minor age, insanity, unavoidable mistake of law) making her/him not blameworthy, as s/he could not have been required to comply with the law in such a case. Excuses are considered to be the most applicable criminal law category for cultural evidence as they require an individualized judgment; and specifically the Article that addresses the Mistake of Law would best apply in Italy. The Mistake of Law is an 
excuse that is put forth under Article 5 of the C.P. Italian criminal law establishes that the defendant can be excused when ignoring criminal rules, only provided that the Mistake of Law is declared unavoidable. It can involve either absolute ignorance of the law or ignorance /mistake through which the defendant is aware of the law but believes that $\mathrm{s} / \mathrm{he}$ is acting lawfully.

Italian judges, confronted with cultural offenses, attribute mistake of law to inadequate social integration; as a result, the defendant earns a complete acquittal if such defense is proved (Basile, 2010; Bartoli, 2005; Bernardi, 2006). This doctrine is widely used to put forward cultural factor by Italian judges. For example, in a recent case (Cass. pen., sez. VI, sent. 22/06/2011, n. 43646) annotated by D'Ippolito (2012) a Nigerian woman, accused of unauthorized exercise of medical science (she had her son circumcised by another woman) was excused. The Court deemed that she did not know Italian law and her Mistake of Law was declared unavoidable, on account of her scarce social integration in Italian society. Although this doctrine is widely used by Italian judges, it may not be the most appropriate; this paper will address our concerns with this application in a subsequent section.

Both justifications and excuses lead to an acquittal when the facts of the case support such a determination. However some cultural offenses, because of their seriousness, cannot be acquitted on account of a cultural factor. In such cases, the cultural background of the defendant may still be considered; however, the consideration is applied at the sentencing stage.

\section{Do Punishments in Italy Consider Culture?}

When an acquittal cannot be achieved through a cultural defense, for instance in cases in which the cultural offender violates the supreme interests, cultural factors can be considered at the punishment stage. This consideration is indirectly referenced under the Italian Constitution and directly referenced in Italian case law; although it should be noted that there is a paucity of case law that directly references culture at sentencing.

Despite the Constitution's loose or indirect reference to punishment goals, Moccia (1992) notes Italian judges do not explain their reasoning when sentencing and they are not prone to consider constitutionally binding punishment aspirations to be obligatory. As a result, Italian case law in which cultural factors have had a mitigating effect, or at least put forth a discussion about this issue, is very scarce.

Nevertheless, there is a case in which the defendant's culture was considered at sentencing. In the case Cass. Pen., VI sez. (26/12/08, n. 46300) a Muslim father was accused of child abuse for battering his daughter in order to reinforce rules put forth in the Quran. The defendant argued that criminal law should have considered his cultural values before charging him. He denied the existence of mens rea on account of a cultural factor; he argued that battering is considered to be a means of education in his culture. The Court rejected his pleading, because constitutional values are an "insurmountable barrier" that prevents defendants from introducing customs, usages and rules that violate human rights. Although he was convicted, the Court of Cassation decided to take defendant's cultural background into consideration at sentencing to ensure that the punishment served a rehabilitative purpose. Unfortunately, the exact punishment was not published; this is common under Italian law. The Supreme Court of Cassation does not generally establish the actual punishment; instead it delegates this responsibility to inferior courts whose verdicts are rarely published.

In contrast, there was a case in which the defendant's culture was considered at sentencing to be justification for increasing the sentence. The Court of Padova, in sent. 09/06/06, n. 446, condemned two Pakistani men, accused of rape; the judge deemed that "the more individual and cultural conditions are different from mainstream culture, the more severe must be punishment, in order to have a deterrent impact on society." The sentence therefore was harsher, in spite of the defendants' request for a lesser punishment on account of a cultural factor.

Although there is a paucity of case law and statute references to cultural consideration at sentencing, there does seem to be enough to signal that Italian law can incorporate cultural considerations at sentencing. However, in cases that violate the supreme interests, Italian law must balance at least two goals of criminal law. On one hand, there is a cultural offender compelled by his/her cultural dogmas and is arguably less blameworthy because of the enculturation phenomenon. However, on the other hand a supreme interest has been violated that has produced a victim and affected public sentiment. 


\section{The Pros, Cons and Potential Pitfalls of Considering Culture}

This section examines the importance of cultural considerations as applied at all stages of Italian law, the creation of laws, the enforcement of laws, and the punishment of offenses. However, this section also recognizes that such considerations cannot be achieved without acknowledging complex dilemmas, confronting competing interests, and encountering potential obstacles.

\section{Pros}

There is both theoretical and pragmatic value in recognizing the perspectives of varied cultures when creating criminal laws. However, we must first acknowledge that these benefits exist when applied to matters that do not offend the supreme interests; De Maglie (2010) notes that criminal law should not intervene in social group dynamics, when offenses do not involve supreme interests. However, even in cases that do offend the supreme interest, there are still benefits to considering culture; the law may not exculpate the offender, but it may benefit from punishing the offender less harshly.

Advocates of cultural diversity argue that cultural pluralism is a value in itself (Harvard Law Review, 1986; Kim, 1997). The pursuit of pluralism is worth protecting even through an exculpatory or mitigating defense. Otherwise, as the Harvard Law Review (1986) notes, there is an "overkill" risk; "in the zeal to quash certain undesirable values or manifestation of those values, the majority may inadvertently destroy desirable values as well" (p. 1302). In addition, the acknowledgment of cultural factors can produce more practical benefits; removing punishment for minor cultural offenses or enacting less punishment for major ones, can promote a more peaceful relationship between the cultural groups that co-exist in a society. This may foster social cohesion, which is an implicit punishment goal noted in the Italian Constitution. It is also arguable that recognizing cultural factors can be a way to rehabilitate the society; Baratta (1976) notes that before changing excluded people, we might change an excluding society by addressing the exclusion process. Furthermore, the promotion of multiculturally inclusive policies and laws are inspired by the pursuit of equality; they acknowledge that existing cultural differences need to be preserved and/or recognized, as minority groups may not have the power to preserve or promote their culture. Authors report this trend in Anglo-Saxon countries (Basile, 2010; Bernardi, 2006; De Maglie, 2010). For instance, laws that endorse affirmative action policies in the United States appreciate the need to recognize culture as an integral part of an inclusive society in which the interests of diverse groups are valued. Such laws strive to prevent inequality in education, work and other public sectors. Furthermore, the British Road Traffic Act (1988) allows Sikh people to wear turbans instead of helmets and the Slaughterhouses Act (1974) allows Muslims and Jews to slaughter animals according to their customs, even if the act is considered to be animal mistreatment. "Treating persons raised in a foreign culture differently should not be viewed as a exercise in favoritism, but rather as a vindication of the principles of fairness and equality that underlie a system of individualized justice" (Harvard Law Review, 1986, p. 1299).

Additionally, considerations of cultural differences when creating law may reduce a trend known in the U.S. as "over-criminalization". Over-criminalization refers to the use of criminal law to solve any social problem. The over reliance of criminal law enforcement occurs because criminal law enforcement is easy to arrange, it does not produce immediate economic costs and it provides electoral consensus. This trend is evident in both Italy and in the U.S. As for cultural offenses, over-criminalization is a rough response to intercultural problems; instead of setting up integration policies, with economic and social interventions, overcriminalization tends to worsen relations with immigrants. Smith (2012) notes that even judges are responsible for over-criminalization, by expanding criminal statutes. Evidence of this can be found in previously mentioned cases in which anti-terrorism laws and laws pertaining to weapons possession have been applied to cases involving cultural offenses, even if these laws were not intended to apply to such cases.

Laws generally resolve only the most frequently occurring and common cultural conflicts. When the recognition of culture does not occur at the law making stage, criminal cases should be able to present a cultural defense. The need for cultural defenses cannot be underestimated, as it is impossible to expect that the law can foresee and/or consider every situation in which a cultural conflict might result. Smith (2012) has noted that, "defenses have a vital role to play in keeping criminal liability within appropriate bounds" ( $p$. 577).

Finally, when cultural factors are not considered at the law making stage or law enforcement stage (e.g., 
trial) there are benefits to considering culture at the punishment stage. Punishments that consider culture are more socially inclusive and reflective of the goals of a democratic state; they ensure that offender rehabilitation, the primary aim of the Italian Constitution, is prioritized. Without acknowledging that the offender's motivations may be rooted in cultural norms and therefore administering a punishment that addresses these cultural norms, true rehabilitation is not possible.

\section{Cons}

Arguments against cultural considerations at all stages of law enforcement draw attention to the rights of the victim. Victims of cultural offenses could be less protected than other victims. Because victims and offenders often share a cultural background (Kymlicka, 1995), a cultural defense is criticized because it could prioritize the strongest members of the group against the traditionally weaker members (e.g., women and children). In addition, the recognition of cultural factors in the law-making process and in trials is said to be able to undermine social cohesion around common values. Kim (1997) notes that the law must lay down rules compelling obedience regardless of an individual's background, in order to maintain social order. A breakdown of social cohesion could adversely affect the majority. Majority members could feel abandoned by their institutions, in particular the law and criminal justice system. Therefore, opponents of a cultural defense may deem that it could, in part, deprive the existing majority society from its own identity.

It can also be argued that cultural considerations negate the need to rehabilitate the offender. These arguments consider cultural offenders to require treatment, since they have violated the law. Therefore, treatment or rehabilitation cannot be achieved if the offense is eliminated, via legal statutes, or justified at trial. Furthermore, the behavior of the offender may be considered to be hostile and dangerous, and without the treatment the offender may pose additional risks to society.

Finally culture, as previously mentioned, is something difficult to define in general and even more so when applied to the law. Furthermore, the impact of acculturation on a society is not static. Therefore, culturally rooted patterns of behavior can change when they interact with other cultures and as such it is arguably difficult to identify which behaviors can be attributed to which culture. Likewise, it can be difficult to recognize behavior as an expression of culture if culture is a result of the integration of foreign values assimilation and the reinforcement of the primary culture.

\section{Potential Pitfalls}

One of potential pitfall of considering culture at point of trial is that case law, rather than statutory law, is better equipped to consider cultural conflicts. Statutory law, as is used in Italy, is written law set down by Parliament; it produces a rigid arrangement of conflicting interests by which only one interest will prevail. But, as we have noted, this arrangement works only when law deals with frequent, common and minor cultural conflict. Other cultural conflicts can amount to what Hart (2012) calls "hard cases"; they are cases in which there is no automatic "right answer". Italian case law, which does not acknowledge precedence, creates a situation in which these issues will be continuously revisited, even if decided in previous cases. Even if it can be a flexible solution for "hard cases", certainty and equality might be jeopardized by this trend in countries, like Italy, where stare decisis is not strictly binding (Basile, 2010; Caputo, 2005). As noted, prior judicial decisions do not strictly bind other judges to follow them. Although, they have a strong persuasive effect, especially when decisions come from the Supreme Court of Cassation, Italian judges can decide differently. As such, a pitfall of considering culture at trial is that, even if it can produce fairer solutions, there is no certainty that the results will set precedence.

In addition to this, Italian jurisprudence is generally conservative regarding what Basile (2010) refers to as "normative cultural elements" (p. 133). Normative cultural elements are words and sentences in laws that can be interpreted very differently on the basis of the cultural values that are the basis of the interpretation. Basile (2010) notes that Italian judges always interpret such language of law, which is sensitive to cultural background by using stereotyping clauses such as "according to mainstream sense", "according to shared social rules", and "according to cultural common heritage". These clauses suggest that there is a generally narrow-minded attitude among Italian judges towards cultural diversity.

Additionally, a general pitfall of culture considerations is the potential stereotyping effect when excuses, rather than justifications, are used at trial. U.S. case law can serve as an example of this. The insanity defense is often used as cultural evidence in 
the U.S., as such in the leading case People v. Kimura, No. A-09113 L.A. Sup. Ct. 1985. The defendant's cultural background was used to prove her mental instability that, in turn, excused her. This excuse had a negative stereotyping effect, treating cultural diversity like mental illness. As Reddy (2002) notes, there is a trend to pathologize cultural factors; this results from attempts to make a defendant's cultural background evaluation more accessible to the court. However, it is also a manifestation of the preemptive power by the dominant culture, which pathologizes the behaviors of the minority culture. When this occurs, the majority culture assumes the role of healer, responsible for fixing the maladjusted minority offender. Paradoxically, cultural considerations can lead to the very outcome that proponents of cultural considerations would like to prevent, cultural exclusion. The social exclusion of cultural offenders can result when they are viewed to be maladjusted, impaired or primitive people. Even more so, since culturally based evidence needs to demonstrate that there was a cultural motivation (that is to say, the cultural offense has to be the result of a group's culture not of a personal belief), the stereotyping effect extends to the entire cultural group.

Finally, all societies, but especially intercultural societies, have to cope with the political ramifications of culture considerations. Consorte (2013) considers that real or supposed failures about immigration policies and the emotional involvement of the people conveyed through the mass-media may push governments to exploit culture diversity in order to gain electoral consensus. This is risk worth taking into consideration when we elaborate on cultural diversity issues, especially referring to criminal law.

\section{CONCLUSIONS}

Although culture is not the only reason for an action, culture has a deep impact on actions; actions are hardly ever a rational outcome of the mere awareness of right and wrong, but more frequently "right" and "wrong" are filtered through cultural values. Therefore, it seems clear that Italy's legal system must address one of the products of its newly intercultural society, cultural offenses. Previous sections have presented Italy's current stance on cultural offenses by presenting relevant laws, cases and reasoning. This section presents suggestions for how Italy might incorporate culturally inclusive legal remedies when confronted with cultural offenses. Before presenting these suggestions we must note that cultural considerations at any stages should only be applied in the offender's favor. Insofar as a society wants minority groups to accept common values, penalizing cultural offenders hardly produces integration; rather cultural offenders, who commit minor offenses, will be alienated. Cultural considerations at any stage, from law creation to punishment that consider culture to be an aggravating factor, violate human rights considerations and the Constitutionally promoted punishment aims. As such, any suggestion must be in accordance with implicit and explicit directives put forth under the Italian Constitution. The Italian Constitution (Article 27) establishes that criminal punishment should prioritize rehabilitation as the central justification of criminal punishment.

We assert that Italian law should adopt a multipronged approach when considering cultural offenses. First, for minor offenses that do not offend supreme interests and are more consistent with culture as a fundamental right, culturally inclusive laws should be the first attempt to officially recognize culture in relation to the law. Second, because no law can be expected to remedy all behaviors, justifications should be considered when minor cultural offenses are presented in Italian courts. Third, when cultural offenses offend supreme interests they cannot be justified as a right to culture, and therefore such offenses should be punished; however, punishments should consider that the defendant's culpability is reduced. Finally, we assert that criminal law is not the most appropriate place to address interculturalism. All too often the criminal justice system is left to handle issues that should be addressed by other social institutions.

\section{Creating Culturally Inclusive Laws}

There is a paucity of culturally inclusive laws for what could be characterized as political laziness. Also, this issue is politically thorny. The majority constituents may rebel if new groups are given consideration; this is of utmost concern given the contemporary economic turbulence in Italy. Therefore, the Italian Parliament rarely passes politically sensitive laws that would be more consistent with Constitution, in essence delegating political responsibilities to judges who must interpret and apply law at trial.

These political elements are compounded by the fact that the Italian legal system does not recognize stare decisis (an interpretation oriented towards Constitution is not binding for future decisions). Therefore, laws are not being passed and culturally inclusive legal decisions do not serve as precedent. Therefore, we assert that culturally inclusive laws must 
be created to handle common, frequent minor cultural offenses; they are more certain and equitable. Moreover, culturally inclusive laws can reduce overcriminalization. Larkin (2013) addresses numerous reasons to avoid over-criminalization. First, he notes that if the penal codes regulate too many behaviors, it becomes difficult for the average person to know what is forbidden; in essence there is no guiding principle. Also, the courts will be less likely to curb law enforcement excesses, because the police will almost always have probable cause to arrest someone for something. Finally, the criminal process will be more easily influenced or corrupted by special interest groups, "because every private party will vie for economic rents by making a criminal out of a rival" ( $p$. 756).

Although Italy rarely opts for culturally inclusive laws, there is at least one instance in which it did. Italian law 439/1978 justifies Muslims and Jews animal slaughtering practices; these practices are not considered to be animal mistreatment crimes, when committed in connection with religious slaughtering. This law was passed in response to European Directive $74 / 577 / C E E$, which states that every animal has to be stunned before slaughtering it. Italian law 439/1978 (article 4) excludes punishment for slaughtering by ritual bleeding. Moreover, the law provides some rules to follow in order to balance religious freedom with animal pain. The law establishes that experienced people must carry out the slaughtering, the knife must be sharp, the throat must be cut immediately, and the animal must not be upset or frightened. This culturally inclusive law is the result of a positive dialogue between the Italian Government and both the Islamic Cultural Center and the Jewish Community Center who asked for permitting such slaughtering. This can become a model to follow in order to introduce similar laws for other minor but frequent cultural offenses that do not necessarily also involve religious considerations (e.g., khat usage does not deal with religion, but it could be justified by a culturally inclusive law). Also, such laws can provide better relations between social groups. For instance, without a rule about ritual slaughtering Jews and Muslims could have decided to buy illegally imported meats, or to slaughter animals in a way that could be considered animal mistreatment.

Culturally inclusive laws can be more practicable and flexible than other legal remedies. They also address the heart of the matter; they are proactive solutions that represent a democratic society committed to respecting individual expressions of behavior. Finally, culturally inclusive law creation should be the bedrock of a democracy. Two of the main principles of a democratic state are to ensure human rights and represent the will of the people; the state, when possible, must ensure these principles apply to all people.

\section{Minor Cultural Offenses: Justifications that Allow Persons to Exercise their Rights}

We deem that minor cultural offenses (offenses that do not offend supreme interests), which cannot be remedied through the creation of culturally inclusive laws, should be justified. Justifications are more suitable than excuses when applied to cultural offenses. First, Article 51 of the C.P (Justification of exercise of right) is a solution that targets cultural conflicts in minor cultural offenses; when culture as a fundamental right is not involved, as such as in cases in which immigrants simply ignore criminal laws without any reference to cultural conflicts, the offense cannot be justified by Article 51 of the C.P. The issue will deal with immigrants criminality, but it is a different, though related, subject as some evidences show (Foblets, 1998; Tonry, 1997; Tonry, 1998). Furthermore, there are less stereotyping effects; justified cultural offenses are not based on a negatively valued motivation, such as the ignorance of law, or insanity, but rather a positively valued motivation (the exercise of a right). As a result, the dominant culture, in cases in which supreme interests are not offended must concede on the basis of cultural pluralism, which should be valued in democratic societies.

\section{Major Cultural Offenses: Non-Negotiable Interests and Sentencing Solutions}

Society must continue to punish certain cultural offenses, in order to defend the values of native people and victim's human rights, even if punishment must never be exemplary or discriminatory. For instance, balancing victim protection with individualizing treatments for cultural offenders is the very matter of criminal law in a multicultural society.

Therefore, we deem that supreme interests, offended by gross violations such as murder, rape, kidnapping, torture, segregation and slavery are not negotiable. In such cases, even when culture is a factor, the action is deserving of punishment. In such cases one's fundamental right to culture cannot be considered; this assertion is not based on an ethnocentric point of view that privileges predominant 
values over those of foreign cultures. On the contrary, supreme interests are the essential foundation of every society, even intercultural societies, and criminal law represents the most fundamental mechanism to defend them. As Höffe (2001) notes, a true "foreigner" does not exist in relation to supreme interests; they belong to the heritage of mankind, and criminal laws defending it tend to undertake a "trans-cultural foundation" (p. 136).

Nevertheless, persons who commit major cultural offenses should receive a mitigated punishment on account of cultural factors. Arguably, the cultural offender is less culpable because her/his action is, consciously or less, more so influenced by his/her cultural norms, on account of the enculturation phenomenon. Punishing the cultural offender in the same way as an offender belonging to cultural majority group would be unfair, because the latter offender's reason to act is not situated in a culturally rooted clash of values. Furthermore, this inequity would have impact rehabilitation attempts; they would be doomed to fail, because a punishment perceived as unfair could adversely impact an offender's perception of the majority group and its institutions, most notably criminal law. Again, an interpretation of statutory law according to Italian Constitution should bind judges to evaluate cultural factors only as a mitigating circumstance, even without a specific law that states this. A mitigated punishment can be a reasonable point of balance between the necessity to punish supreme interest violations and the consideration of the cultural offender's mitigated culpability; rehabilitation could produce fairer solutions. Cultural offenders would understand that their behavior is not acceptable, but they would be aware that the law considered their culture, making them more prone to reintegrate peacefully.

Additionally, Article 133 of the C.P. could be slightly modified, making rehabilitation purposes clearer than they are now. For instance, cultural motivations might be explicitly inserted into the article. The article could demand a consideration of cultural rules shared and observed by cultural offenders' group, whose compliance would have influenced a cultural offender's conduct. This modification could make judges more prone to consider culture at sentencing. Unfortunately, it appears that the political and social atmosphere is far from allowing Italy to make these statutory reforms.

Some sentencing guidelines already mentioned by Article 133 of the C.P. could serve the purpose of mitigating punishment. For instance, by considering either "criminal purpose" or "individual, familiar and social conditions of the offender" the judges can already consider the cultural background of the offender, but in the previous sections we have noted the paucity of cases considering culture in sentencing phase. Therefore, either a new sentencing guideline or a re-interpretation of some existing guidelines may require an improvement in judicial attitudes towards cultural diversity. Additionally, anthropologist and sociologist witnesses should be more widely admitted in order to highlight the cultural conflict behind the offense in the trial. The judge may not have enough knowledge to follow the cultural arguments; s/he will need an expert witness, usually an anthropologist, whose testimony is reliable and relevant (Kim, 1997).

\section{Is Criminal Law the Right Place to Address Cultural Conflicts?}

We think that this overall solution may require a balance between criminal law remedies and social integration policies. The tensions resulting from competing cultural interests cannot be remedied by criminal law. This is not to say that decriminalization is always advantageous; Hart (1963) notes that the majority has the right to follow their own moral convictions and preserve their "moral environment". However, the preservation of the moral environment must be balanced. This balance can only be achieved when other institutions, such as social services, the educational system and private law further develop their cultural integration policies; thus, reducing the burden on criminal law solutions. These policies should not focus on orientating the immigrant to accept the value system, yet rather these integration policies should encourage a dynamic exchange between the existing majority group and new groups. For instance, the educational system could introduce students to foreign cultural behaviors, by embracing cultural events that promote international cuisines, and scholars and writers other than Italians, other Europeans and Americans. Likewise, working times should be arranged so that ritual times for prayer could be observed, and important holidays could be celebrated.

Cultural conflicts cannot be avoided; humans when confronted with anything new are instinctually cautious and skeptical. However, Italy must recognition that integration and cultural inclusion is good for the sum of its parts. The minority culture will feel acknowledged and thus be more likely to be economically, politically and emotionally engaged residents. The majority will feel their culture is worth preserving as policies to 
integrate new groups simultaneously acknowledge the new culture, while maintaining the existing culture's general principles. Furthermore, integration policies adopted by various institutions will increase social cohesion and reduce unfortunate consequences of multiculturalism: animosity, distrust, and intolerance. These consequences must be avoided in order to promote the goals of the Italian Constitution, which "recognize the dignity of the person, both as an individual and in social groups."

\section{REFERENCES}

Baratta, A. (1976). Sistema Penale ed Emarginazione Sociale. Per la Critica dell'Ideologia del Trattamento. La Questione Criminale, 2, 237-259.

Bartoli, R. (2005). Colpevolezza: Tra Personalismo e Prevenzione. Torino, Italia: Giappichelli.

Basile, F. (2010). Immigrazione e Reati Culturalmente Motivati: II Diritto Penale nelle Società Multiculturali. Milano: Giuffrè.

Bernardi, A. (2006). Modelli penali e Società Multiculturali. Torino, Italia: Giappichelli.

Bernardi, A. (2010). II "Fattore Culturale" nel Sistema Penale. Torino, Italia: Giappichelli.

Campbell, E. (2012). Law/Culture: Powers, Politics and the Political. International Journal of Criminology and Sociology, 1, 1-12. http://dx.doi.org/10.6000/1929-4409.2012.01.1

Caputo, A. (2005). La Giurisdizione e i Conflitti Culturali. Questione Giustizia, 4, 710-725.

Consorte, F. (2013). Fattore culturale e Diritto penale. Spunti di Riflessione a Partire dall'Ordinamento di Francia, Inghilterra e Israele. Cultura, Culture e Diritto Penale, edited by L. Stortoni, S. Tordini Cagli. Bologna, Italia: Bononia University Press, 27-37.

Chiu, D. C. (1994). The Cultural Defense: Beyond Exclusion, Assimilation, and Guilty Liberalism. California Law Review, 82(4), 1053-1126. http://dx.doi.org/10.2307/3480939

De Maglie, C. (2010). I Reati Culturalmente Motivati: Ideologie e Modelli Penali. Pisa, Italia: Edizioni ETS.

Del Corso, S. (2011). Art. 51 c.p. Codice Penale. Vol. 2, edited by T. Padovani, 5th ed. Milano, Italia: Giuffrè.

D'Ippolito, E. (2012). Kulturnormen ed Inevitabilità dell'Errore sul Divieto: La Corte di Cassazione Riconosce l'Errore Determinato da Fattori Culturali come Causa di Esclusione della Colpevolezza. Annotation to Cass. Pen., sez. VI, sent. 22 giugno 2011, n. 43646. Cassazione Penale, 11(52), 37113720 .

European Migration Network. (2012). Canali Migratori. Visti e Flussi Irregolari, Quarto Rapporto. Roma: EMN/Ministero dell'Interno.

Eurostat. (2011). 6.5\% of the EU Population are Foreigners and 9.4\% Are Born Abroad. Statistics in Focus 34.

EURISPES. (2006). Gli Italiani e la Chiesa: Tra Fedeltà e Disobbedienza. Diciottesimo Rapporto Italia 2006, Roma: Eurilink.

EURISPES. (2010). Gli Italiani e la Fede. Ventiduesimo Rapporto Italia 2010. Percorso di Ricerca nella Società Italiana. Roma: Eurilink.

Foblets, M. C. (1998). Cultural Delicts: The Repercussion of Cultural Conflicts on Delinquent Behaviour. Reflections on the Contribution of Legal Anthropology to a Contemporary Debate. European Journal of Crime, Criminal Law and Criminal Justice, 6(3), 187-207. http://dx.doi.org/10.1163/15718179820518485
Gatta, G. (2009). Islam, Abbigliamento Religioso, Diritto e Processo Penale: Brevi Note a Margine di Due Casi Giurisprudenziali. Stato, Chiese e Pluralismo Confessionale. Retrieved from http://www.statoechiese.it/images/stories/2009.6/gatta_islam m.pdf

Geertz, C. (1973). The Interpretation of Cultures. New York: Basic Books.

Grosso, E. (2006). Multiculturalismo e Diritti Fondamentali nella Costituzione Italiana. Multiculturalismo, Diritti Umani, Pena, edited by A. Bernardi. Milano, Italia: Giuffrè, 109-136.

Hart, H. L. A. (2012). The Concept of Law. 3rd ed. edited by J. Raz and P. A. Bullock. Oxford: Oxford University Press.

Hart, H. L. A. (1963). Law, Liberty, and Morality. Stanford, CA: Stanford University Press.

Harvard Law Review (1986). The Cultural Defense in the Criminal Law. Harvard Law review, 99(6), 1293-1311. http://dx.doi.org/10.2307/1341255

Heller, K. J. (2012). Cultural defense. Retrieved from http://uscivilliberties.org/themes/3670-cultural-defense.html? newsid $=3670 \&$ seourl $=$ cultural- defense\&seocat=themes, on October 16, 2013.

Höffe, O. (2001). Globalizzazione e Diritto Penale. Translated by S. Dellavalle. Torino, Italia: Edizioni di Comunità.

Horowitz, L. D. (1986). Justification and Excuse in the Program of the Criminal Law. Law and Contemporary Problems, 49, 109126. http://dx.doi.org/10.2307/1191628

Institute of Caritas-Migrantes. (2011). Rapporto sull'Immigrazione. Roma: Edizioni Idos. http://www.caritas.it/materiali/Pubblicazioni/libri_2011/dossier_immigrazione2011/scheda.pdf

ISTAT. (2009). Cittadini Stranieri Residenti per Regione e Provincia, Area Geografica e Paesi Cittadinanza, al $1^{\circ}$ Gennaio 2008.

ISTAT. (2012a). Natalità e fecondità della Popolazione Residente Relativo all'Anno 2011.

ISTAT. (2012b). Rapporto ISTAT - Cittadini Non Comunitari Regolarmente Presenti per Sesso, Area Geografica e Singolo Paese di Cittadinanza, al $1^{\circ}$ Gennaio 2011.

ISTAT (2013a). Rapporto ISTAT - Popolazione Straniera Residente in Italia al $1^{\circ}$ Gennaio 2013. Retrieved from http://www.istat.it/it/archivio/96694, on October 15, 2013.

ISTAT (2013b). Indicatori Sintetici di Confronto tra Italiani e Stranieri. Retrieved from http://www.istat.it/it/immigrati/indicatorisintetici/confronto-italiani-stranieri, on October 15, 2013.

Kim, N. S. (1997). The Cultural Defense and the Problem of Cultural Preemption: A framework for Analysis. New Mexico law Review. Retrieved from http://lawlibrary.unm.edu/nmlr/ volumes/27/1/04_kim_cultural.pdf, on October 16, 2013.

Kymlicka, W. (1995). Multicultural Citizenship: A Liberal Theory of Minority Rights, Oxford: Oxford University Press.

Kluckhohn, C., \& Kroeber, A. (1952). Culture. A Critical Review of Concepts and Definitions. Cambridge: Mass.

Larkin, P. J. (2013). Public choice Theory and Overcriminalization. Harvard Journal of Law and Public Policy, retrieved from http://www.readperiodicals.com/201304/2969053371.html\#b on October 26, 2013.

Mezzetti, L. (2013). Cultura e Culture: Paradigmi di Tutela e Protezione Multilivello. Cultura, Culture e Diritto Penale, edited by L. Stortoni, S. Tordini Cagli. Bologna, Italia: Bononia University Press, 13-26.

Moccia, S. (1992). II Diritto Penale tra Essere e Valore: Funzione della Pena e Sistematica Teleologica. Napoli, Italia: Edizioni Scientifiche Italiane.

Monticelli, L. (2003). Le "Cultural Defenses" (Esimenti Culturali) e "Reati Culturalmente Orientati". Possibili Divergenze tra Pluralismo Culturale e Sistema Penale. Indice Penale 6(2), 535 - 585. 
Meer, N., and Modood, T. (2012). How does Interculturalism contrast with Multiculturalism?. Journal of Intercultural Studies, 33(2), 175-196. http://dx.doi.org/10.1080/07256868.2011.618266

Post, Robert C., "Law and Cultural Conflict" (2003). Faculty Scholarship Series. Paper 180. Retrieved from: http://digitalcommons.law.yale.edu/fss_papers/180

Provera, A. (2010). II "Giustificato Motivo": La Fede Religiosa come Limite Intrinseco della Tipicità. Annotation to Trib. Cremona, 19 Febbraio 2009, n. 15. Rivista Italiana di Diritto e Procedura Penale, 53(2), 964-979.

Reddy, S. (2002). Temporarily insane: pathologising cultural difference in American criminal courts. Sociology of Health and IIIness 24(5), pp. 667-687. http://dx.doi.org/10.1111/1467-9566.00313

Renteln, D. A. (2009). The Cultural Defence: Challenging the Monocultural Paradigm. Cultural Diversity and the Law: State Responses from around the World, edited by M. C. Foblets, J. F Gaudreault - Desbiens and A. D. Renteln. Bruxelles: Bruylant, Pp. 791-817.

Renteln, D. A. (2004). The Cultural Defense. New York: Oxford University Press.

Roxin, C. (1973). Kriminalpolitik und Strafrechtssytem, 2nd ed. Politica Criminale e Sistema del Diritto Penale, translated and edited by S. Moccia, Napoli, Italia: Edizioni Scientifiche Italiane, pp. 37-82. http://dx.doi.org/10.1515/9783110903577
Smith, F. S. (2012). Overcoming Overcriminalization. The Journal of Criminal law and Criminology,102(3), 537-592. Retrieved from: http://www.law.northwestern.edu/journals/jclc/backissues/ v102/n3/1023_537.Smith.pdf on 22 October 2013.

Tylor, B. E. (1871). Primitive Culture. Researches into the Development of Mythology, Philosophy, Religion, Language, Art and Custom. London: J. Murray.

Tonry, M. (1997). Ethnicity, Crime and Immigration. Crime and Justice, Ethnicity, Crime and Immigration: Comparative and Cross-National Perspectives, 21, 1-29. http://dx.doi.org/10.1086/449248

Tonry, M. (1998). A Comparative Perspective on Minority Groups, Crime and Criminal Justice. European Journal of Crime, Criminal Law and Criminal Justice, 6(1), 60-73. http://dx.doi.org/10.1163/157181798X00256

Van Broeck, J. (2001). Cultural Defence and Culturally Motivated Crimes (Cultural Offences). European Journal of Crime, Criminal Law and Criminal Justice, 9(1), 1-32. http://dx.doi.org/10.1163/15718170120519282

Valier, C. (2003). Foreigners, crime and changing mobilities. British Journal of Criminology, 43, 1-21. http://dx.doi.org/10.1093/bjc/43.1.1

Viganò, F. (2006). Art. 51 c.p. Codice Penale Commentato, Vol. 2, edited by E. Dolcini - G. Marinucci, 2nd ed. Milano, Italia: IPSOA.

\section{DOl: http://dx.doi.org/10.6000/1929-4409.2015.04.15}

(C) 2015 Muzzica et al.; Licensee Lifescience Global.

This is an open access article licensed under the terms of the Creative Commons Attribution Non-Commercial License (http://creativecommons.org/licenses/by-nc/3.0/) which permits unrestricted, non-commercial use, distribution and reproduction in any medium, provided the work is properly cited. 